\title{
Governing the post mortem procurement of human body material for research
}

\author{
Van Assche K, Capitaine L, Pennings G, Sterckx S
}

\section{INTRODUCTION}

Human biological material is increasingly being used for research purposes. In combination with associated health-related data, research on human biological material allows researchers to investigate the effects of genetic predisposition, life-style and exposure to environmental factors. In this way, research on human biological material holds great promise for the development of diagnostic and therapeutic tools and disease-preventing strategies.

Biological material may be procured not only from living persons but also from the dead. Biological material removed post mortem is a particularly valuable resource for research, especially because some tissues generally only become available after death (e.g. brains, hearts, and metastasized tumors). Considering the enormous efforts that are currently being made to study the biochemical processes and possible genetic causes that underlie cancer and cardiovascular and neurodegenerative diseases, it is likely that biological material removed post mortem will continue to gain in importance.

The removal and storage of biological material from the deceased raises specific ethical concerns. As has recently been highlighted in various post mortem organ retention scandals in England, Wales, Scotland and Australia, severe ethical problems arise when proper consent is not sought (English and Sommerville 2003; Thomas 2002). In the wake of the outrage caused 
by the scandals in the Bristol Royal Infirmary and Liverpool's Alder Hey Hospital, ${ }^{1}$ the Human Tissue Act 2004 and Human Tissue (Scotland) Act 2006 came into force in the UK. Subject to criminal sanctions, the post mortem removal of human biological material for research is now only allowed in the UK after so-called 'appropriate consent' is given. If the deceased person had not given explicit consent, that consent must be obtained from a 'nominated representative' or, in the absence of such, from a person who stood in a qualifying relationship with the deceased. $^{2}$

In countries operating an explicit consent or so-called 'opt-in' system for post mortem organ donation, similar provisions apply to post mortem removal of body material for research. Likewise, some countries operating a presumed consent or so-called 'opt-out' system for post mortem organ donation for transplantation have recently extended the presumed consent system to post mortem removal of human body material for research. This has happened in Spain, France and Belgium. It has resulted in a twofold extension of the presumed consent regime that governs cadaveric organ transplantation: first, an extension from post mortem removal of organs to post mortem removal of any human body material that falls under the scope of the applicable law on human body material, and secondly, an extension from post mortem removal for transplantation purposes to post mortem removal for research purposes.

In Spain, this extension was introduced by the Royal Decree of 18 November $2011 .^{3}$ The Decree allows removal of body material after death for research purposes when the

1 Bristol Royal Infirmary Inquiry. 2001. "The Report of the Public Inquiry into Children's Heart Surgery at the Bristol Royal Infirmary 1984-1995." July 18. Accessed January 20, 2013. http://www.bristolinquiry.org.uk/final_report/the_report.pdf and Royal Liverpool Children's Inquiry. 2001. "Royal Liverpool Children's Inquiry Report." January 30. Accessed March 18, 2013. http://www.rlcinquiry.org.uk/download/index.htm.

2 Human Tissue Act 2004, Part I, 2-5.

3 Real Decreto 1716/2011, de 18 de noviembre, por el que se establecen los requisitos básicos de autorización y funcionamiento de los biobancos con fines de investigación biomédica y del tratamiento de las muestras biológicas de origen humano, y se regula el funcionamiento y organización del Registro Nacional de Biobancos para investigación biomédica, Art. 26. 
deceased person had expressed consent or at least had not indicated opposition. In the latter case, efforts must be made to gather information about the wishes of the deceased person, by exploring the existence of advance directives or, in the absence of these, by consulting the nextof-kin and health care professionals involved in the treatment of the person concerned. If there is no indication of the deceased person's wishes, removal is allowed unless the next-of-kin provide reasonable objections. Removal is only permitted if it is performed within the framework of a research protocol that has been approved by a Research Ethics Committee.

In France, a presumed consent system for post mortem removal of human body material for research was introduced by the Law $N^{\circ} 2004-800$ on Bioethics of 6 August 2004. ${ }^{4}$ The Law amended the Health Act in a way that allows post mortem removal of body material for research if the person concerned had not indicated refusal. The opportunity is offered to register refusal in a special national registry. In the absence of registered refusal, the next-of-kin must be consulted about the wishes which the deceased might have expressed in this regard. If there is no indication of the deceased person's wishes, the removal will be permitted. The next-of-kin should be duly informed about the purpose of the removal and have the right to be informed about what body material has been removed. The Agency of Biomedicine has to grant prior approval of the research protocol and needs to be informed prior to any removal.

Whereas specific protective measures are in place in both the Spanish and French regulations, this is not the case in Belgium. Concerning post mortem removal of human body material for research, the Belgian law on human body material of 19 December $2008^{5}$ simply

4 Loi n 2004-800 du 6 août 2004 relative à la bioéthique.

5 Wet inzake het verkrijgen en het gebruik van menselijk lichaamsmateriaal met het oog op de geneeskundige toepassing op de mens of het wetenschappelijk onderzoek/Loi relative à l'obtention et à l'utilisation de matériel corporel humain destiné à des applications médicales humaines ou à des fins de recherche scientifique, Art.12. Official versions of the law exist only in Dutch and French. 
refers to the provisions regarding presumed consent in the Organ Transplantation Law of 13 June $1986{ }^{6}$

The Belgian law of 2008 equates the absence of any registered objection to post mortem removal of organs for transplantation with the absence of any objection to post mortem removal of any body material for any purpose. Thus, the law permits post mortem removal of body material from any corpse, unless the deceased person has objected to post mortem removal of organs for transplantation. No separate 'opt-out' register has been put in place for registering objections to post mortem uses of body material for research. However, the Belgian population is unaware of this law. Neither the government nor any other organization has made any effort whatsoever to inform the public of this new legal regime for the post mortem procurement of body material. As a result, any citizen who objects to post mortem removal of his or her body material for research will obviously fail to register this objection.

Thus, in practice, the new Belgian presumed consent system amounts to a routine removal of body material after death whenever a clinician or researcher: (1) finds a specific post mortem removal useful for research; (2) has access to a dead body; and (3) neither the deceased nor the next-of-kin object(ed) to post mortem removal of organs for transplantation.

In this paper, we attempt to determine which consent regime should govern the post mortem procurement of body material for research. We first analyze whether a regime of conscription or compulsory removal is ethically acceptable. We will assess the various arguments that could be put forward in support of a duty to make body material available for research purposes after death. Our analysis suggests that a duty to make one's body material available for research after death can be substantiated on at least two grounds (a duty to refrain from free-riding and a duty to contribute to the maintenance of public goods) and possibly also

\footnotetext{
6 Wet betreffende het wegnemen en transplanteren van organen/Loi sur le prélèvement et la transplantation
} d'organes, Art. 10-13. Official versions of the law exist only in Dutch and French. 
on a third ground (a duty of easy rescue, depending on how such a duty is interpreted), but that this duty is always conditional. We conclude that this duty could support conscription but only as a last resort and only if a way were found to guarantee that two conditions that attach to the duty would be met. Since neither of these two criteria is currently fulfilled, conscription must be rejected. We conclude, however, that the duty to make body material available for research purposes after death is sufficiently strong to defend a policy of presumed rather than explicit consent.

\section{ARGUMENTS IN SUPPORT OF A DUTY TO MAKE BODY MATERIAL}

\section{AVAILABLE FOR RESEARCH AFTER DEATH}

A duty to make body material available for research after death could be advocated on the basis of two more fundamental duties: a duty of fairness towards research participants for having benefited from the results of research and a duty of beneficence, on the assumption that this type of contribution to research will prevent harm and does not imply a significant sacrifice. In this section, we will examine these arguments and indicate to what extent, if at all, they could support a duty to make one's body material available for research after death.

\subsection{Duty of Fairness}

It could be argued that people have a duty to make their body material available for research purposes after they die, out of fairness for having benefited from the results of biomedical research throughout their life. Following Rawls' (1971) principles of justice, the duty of fairness implies that people who benefit from participating in cooperative social schemes have duties towards each other to assume, when called upon, the risks and burdens which accompany the involvement in such social schemes. On the basis of such a duty, several 
prominent bioethicists have argued for a general duty to participate in biomedical research which, it is implied, could also require persons to allow research to be performed on their remains (Caplan 1984; Harris 2005; Rhodes 2008). The duty of fairness can be split up into two more specific duties: a duty to refrain from free-riding and a duty to contribute to the maintenance of public goods. In the following two subsections, we analyze each of these duties and argue that they both support a conditional duty to make body material available for research after death.

\subsubsection{Duty to refrain from free-riding}

Some bioethicists argue that people who do not take part in biomedical research, while at the same time accepting its benefits, are free-riding on the backs of those who do participate (Evans 2004; Harris 2005; Orentlicher 2005; Rhodes 2005). As we all (at least in industrialized countries) gain from the results of biomedical research, they argue, non-participants have an outstanding moral debt which implies a duty to also participate in biomedical research.

Free-riding occurs when a person obtains a benefit resulting from the efforts of others and this person refuses to assume part of the burdens involved in bringing about the benefit. It could be argued that, although a moral debt will result from gaining from biomedical research in general, this moral debt can be made up for in other ways than participation in biomedical research. From this perspective, it is overly simplistic to label as free-riders those who benefit from biomedical research without themselves having participated. After all, almost all people already pay - via taxes, insurance policies or out of their own pockets - for almost every medical benefit they enjoy (Brassington 2011; de Melo-Martin 2008). In addition, they often also indirectly support - through taxes - biomedical research projects. However, according to this line of reasoning, it may be asserted that the small minority of individuals who do not 
financially support biomedical research can still be accused of free-riding and may fairly be expected to make up for their moral debt by participating in person. In response, it can be pointed out that the likely unfairness that leaves persons in a position of not being able to contribute financially may override obligations stemming from being free-riders. ${ }^{7}$

By contrast, if the focus is shifted to the moral debt arising from benefiting from specific knowledge resulting from biomedical research on body material, the conclusion that non-participation amounts to free-riding is much harder to escape. After all, specific biomedical research cannot be carried out on the basis of financial contributions alone (Chan and Harris 2009; Forsberg, Hansson, and Eriksson 2014). It could therefore be argued that a moral obligation exists to allow post mortem removal of one's body material for research. However, this duty is conditional in that it will not attach to persons who have already donated samples while alive. Furthermore, it will only extend to types of research similar to the ones from which these persons had actually benefited.

\subsubsection{Duty to contribute to the maintenance of public goods}

A second argument put forward in support of a general duty to participate in biomedical research invokes the concept of 'public goods'. A public good exhibits the characteristics of 'non-rivalry' and 'non-excludability'. Non-rivalry implies that a person can use the good without diminishing the amount available for others. Non-excludability refers to the impossibility of excluding anyone from enjoying the benefits of the good, even if they contributed nothing to its provision (Clark, Kotchen, and Moore 2003). Some claim that the knowledge resulting from biomedical research represents a public good. Given that we all

\footnotetext{
7 We thank one of the anonymous reviewers for pointing this out.
} 
benefit from generalizable biomedical knowledge, it is argued, we have a duty to contribute to the advancement of such knowledge by participating in biomedical research (Schaefer, Emanuel, and Wertheimer 2009). Again, this implicitly could require persons to allow post mortem removal of their body material for research.

The abovementioned argument has encountered major resistance. A first criticism challenges the public good status attributed to biomedical knowledge on the grounds that disadvantaged groups have no (or limited) access to healthcare (de Melo-Martin 2008). It is rightly stressed that in the industrialized world, access to the results of biomedical research also depends on factors such as one's financial situation (health insurance), the availability of preventative healthcare and the extent to which information concerning medical solutions and developments is conveyed. In response, however, it can be pointed out that this argument does not seem generally applicable to countries operating welfare states where, at least in principle, access to basic healthcare is also provided for otherwise disadvantages groups. ${ }^{8}$ Moreover, lack of access to healthcare does not preclude other ways of benefiting from biomedical knowledge. For example, people who do not have access to a vaccine will benefit from herd immunity as long as a substantial number of other persons are vaccinated. To mention another example, research conducted at the beginning of the last century demonstrated an inverse relationship between higher fluoride concentration of the drinking water and lower levels of dental caries experience (Ripa 1993). Based upon this finding, numerous countries have adjusted the water fluoride concentration to a level expected to promote dental health. Up until today, both the rich and the poor in those countries benefit from this practice.

A second line of criticism argues that many biomedical research projects do not result in a public good. In this regard, three types of arguments are put forward. First, it is stressed that many research projects do not yield any relevant results and thereby fail to produce a public

\footnotetext{
8 We thank one of the anonymous reviewers for pointing this out.
} 
good (Holm, Hofmann, and Solbakk 2009). Second, it is pointed out that a lot of research is carried out in a way that hampers other researchers from obtaining useful results in the same field and, thereby, hinders the development of public goods. Typical measures include the refusal to publicly report findings and the use of patenting and licensing practices, which may stall subsequent research and the development of diagnostic and therapeutic tools (Sterckx 2011; Cockbain and Sterckx 2011). Third, it is observed that biomedical research projects may also be harmful to the participants. Even in the absence of physical harm, there is a possibility of researchers exploiting research participants by viewing them merely as a means to achieving prestige and/or wealth, as in the cases of, for example, the late John Moore (see Moore v. Regents of University of California 1990) and the members of the Havasupai tribe in the United States (Van Assche, Gutwirth, and Sterckx 2013). Furthermore, research results may, for example in the case of genetic research, also be used for insurance or employment discrimination or be stigmatizing for the research participant or the wider group (Ashburn, Wilson, and Eisenstein 2000; Van Assche and Sterckx 2014). However, these arguments miss the point since they do not refute the public good status of biomedical knowledge but merely emphasize that research should be carried out in a proper way.

A final group of critics acknowledges the public good status of biomedical knowledge, but disputes the claim that research participation is required in order to discharge the duty to contribute to the maintenance of the public good. However, as we have argued in the context of free-riding, biomedical research cannot be carried out on the basis of financial contributions alone. It could therefore be argued that, to the extent that biomedical knowledge can only be attained by direct participation of individuals, the duty to maintain the public good will result in a duty to participate.

On this basis, a duty may be said to exist to contribute to the maintenance of biomedical knowledge by post mortem donation of body material for research purposes. However, it 
should be stressed that this duty is conditional. Following the general principle of fairness, persons who have donated body material whilst alive will already have done their fair share. Moreover, the duty will only extend to research projects which focus on obtaining biomedical knowledge that would unquestionably qualify as a public good.

\subsection{Duty of Beneficence}

An additional argument that could be invoked to substantiate a duty to make one's body material available for research purposes after death does not focus on the duty of fairness but on the duty of beneficence. The latter implies that we have to act in ways that prevent or remove harm or that confer benefit (Beauchamp and Childress 2013). According to some commentators, given that biomedical research represents a necessary tool for alleviating the plight of patients, we have a moral duty to participate in biomedical research (see, for example, Harris 2005). If such a duty were to be established, this could require people to allow post mortem removal of their body material for research. In this respect, a distinction needs to be made between the general duty of beneficence and the more specific duty of easy rescue. In the following subsections both duties will be analyzed and it will be argued that the duty of easy rescue can only support a conditional duty to make body material available for research after death.

\subsubsection{General duty of beneficence}

While the duty of non-maleficence (i.e. the duty to refrain from causing harm) can be considered as a perfect duty, the general duty of beneficence is merely an imperfect duty (Shapshay and Pimple 2007). The assumption of a perfect moral duty to help others is untenable, for at least two reasons. First, such a duty would require too great an effort because it would command people to continuously engage in a wide range of actions of benefit to 
society (Murphy 2000). Second, a perfect moral duty of beneficence would also undermine our moral integrity. Given that there are many ways in which harm to others can be limited, we would be obliged to spend most of our time, energy and resources on combating poverty, hunger, and wars, rather than on projects which minimize harm to others to a lesser extent. As Williams has convincingly argued, a perfect moral duty of beneficence would reduce an individual to a 'harm-minimizing instrument' lacking any integrity. After all, his/her actions would not correspond to his/her convictions and life projects (Williams 1990).

An imperfect duty to help others implies that we ought to view the happiness of others as an end in itself. However, at the same time we are given great leeway in achieving this goal. We are allowed to weigh up this end against other (possibly private) ends. Thus, the pursuit of others' happiness need not always be prioritized (Hill 1992). If we acknowledge the existence of an imperfect moral duty to help others, the question arises as to why this duty would entail obligatory participation in biomedical research, including making our body material available for research after death (Shapshay and Pimple 2007; Wachbroit and Wasserman 2005).

The duty of beneficence requires us to support our fellow-man. There are various ways of achieving this end, however, many of which are much more effective than participation in biomedical research (de Melo-Martin 2008). Even if the fight against disease were our primary task, it is not clear why participation in research is the only or even the best way of achieving this. Biomedical research (especially in its current form) may not represent the best means of reducing the global burden of disease. Given the close link between poverty and disease, fighting poverty would probably constitute a much more efficient means of combating disease (Woolf et al. 2007; Pogge 2002).

In sum, if we consider the question at issue here from the perspective of a general duty of beneficence, the conclusion seems to be that, whereas people may have very good reasons to 
make their body material available for research after death, they are not required to do so. It is up to them to decide whether and, if so, under what conditions, they want to fulfill their duty of beneficence by engaging in precisely this type of act.

\subsubsection{Duty of easy rescue}

However, under certain specific circumstances the duty of beneficence may be a perfect duty, in which case the discretion normally allowed by beneficence is eliminated. This is frequently referred to as the 'duty of easy rescue'. The duty of easy rescue was first elaborated by Thomas Aquinas and has been introduced in bioethics by ethicists like Peter Singer and Michael Slote. In a relatively old, but still very influential article concerning famine and ethics, Peter Singer (1972) argued, on the basis of his famous thought experiment about a child drowning in a pond, that we are morally obliged to prevent harm whenever we are able to do so without having to sacrifice anything of comparable moral significance. Similarly, Michael Slote (1977) endorses the view that we have a duty to prevent serious harm whenever we are able to do so without interfering with our own life plan and without incurring serious harm. According to Beauchamp and Childress (2013, 206-9), there is an obligation to rescue if five cumulative conditions are fulfilled: (1) someone is at risk of significant loss of or damage to life, health or another basic interest; (2) another person's action is required in order to prevent this loss or damage; (3) this action will probably prevent the loss or damage; (4) this action involves no important risks, costs or burdens for the other person; and (5) the expected gain for the person in need outweighs any likely harms, costs or burdens for the other person.

The duty of easy rescue is frequently used to justify an obligation of post mortem organ donation for transplantation, even to the point of advocating a system of conscription (Fabre 2006; Hester 2006; Snyder 2009; Spital and Taylor 2007). However, even if an obligation to donate one's organs for transplantation after death could be established on the basis of a duty of 
easy rescue, a similar obligation to make one's body material available for research purposes after death seems harder to substantiate.

In the case at hand the first two conditions seem to be met since many individuals at significant (future) health risk will arguably substantially benefit from other person's post mortem donation of body material for research. With regard to the third condition, discussion may arise as to how likely it needs to be that the post mortem donation of body material by a third person will prevent the health loss of the other person. In addition, uncertainty may exist as to how obvious the causal link between the contribution and the health benefit has to be. On the one hand, it can be argued that, even if a high probability of success and a clear causal relationship can be difficult to demonstrate, a duty of easy rescue may be defended if one factors in that this kind of health relief can only be achieved by collective and sustained action. On the other hand, the stock examples of easy rescue presented in the literature (e.g. assistance from bystanders which does not put them in harm's way; post mortem organ donation) seem to suggest that, at the time of the required action, both the rescuer and the person in peril have to be clearly identified and that the action of one and only one person is required to help the person in need (James 2007; Smith 1990). In view of these considerations regarding the third condition of easy rescue, it seems clear the applicability of a duty of easy rescue can neither be easily substantiated nor simply discarded for the topic at issue here, i.e. making body material available after death for research purposes.

Taking into account the fourth condition, a duty of rescue will only apply where the action that is required does not represent significant risks, costs or burdens to the person concerned (otherwise the rescue would not be 'easy'). However, although this is frequently assumed, it is not at all obvious that the type of biomedical research at issue here - research on human body material - cannot involve important harms and wrongs. Some people may conscientiously object to the removal itself because of beliefs that the body should be buried as 
a whole. For these persons the costs incurred may be substantial and even disproportionate when compared to the expected benefits of their contribution.

Even for people who do not find the removal in itself objectionable, a lot could be at stake. As has already been highlighted, research on human body material may involve severe infringements upon the privacy, autonomy, or moral integrity of the research participants. Indeed, body material may be used in a way that is incompatible with the moral values of the person concerned. In this context it should be noted that, following Ronald Dworkin's (1993) terminology, so-called 'critical interests' may be at stake. ${ }^{9}$ Such interests are bound in the projects, plans and choices that persons have made and that give meaning to their life. When meaningful life plans are made, it is important for the individual that others respect them and do not take actions that will critically impact on them in a negative way. From this perspective, people are entitled to their body material being used in a manner that corresponds to their life story, character, and values. ${ }^{10}$ Failure to respect this would amount to instrumentalization. ${ }^{11}$ As bioethicist Julian Savulescu has put it:

Each mature person should be the author of his or her own life. Each person has values, plans, aspirations, and feelings about how that life should go. People have values which

9 'Critical interests' need to be distinguished from so-called 'experiential interests' which are related to the pursuit of pleasurable experiences. Contrary to 'critical interests', the setback of experiential interests will be temporarily frustrating at most (Dworkin 1993).

10 As the US National Bioethics Advisory Commission already observed in 1999, anonymization of the body material cannot invalidate this claim: "It is incorrect to assume that because the sources cannot be identified they cannot be harmed or wronged. [...] Individuals have an interest in avoiding uses of their tissues they regard as morally impermissible or objectionable. Thus, were their materials to be used in research that they would consider objectionable, it is possible that some individuals could be wronged, if not harmed" (NBAC 1999, 61). At most, anonymization might offer protection with regard to privacy, although several recent studies suggest that even this cannot be guaranteed (McGuire and Gibbs 2006; Schmidt and Callier 2012; Lowrance and Collins 2007).

11 We are not suggesting here that the instrumentalization argument holds generally, i.e. that it is never permissible to do something to a competent person that does not correspond to their life story, values and character. In exceptional cases coercion might be permissible (e.g. mandatory immunization; coerced placement and treatment) but these interventions find their justification in averting a grave and direct danger to the person concerned, third parties or society at large. These conditions do not apply to (post mortem) removal of body material for research. 
may collide with research goals [...]. To ask a person's permission to do something to that person is to involve her actively and to give her the opportunity to make the project a part of her plans. When we involve people in our projects without their consent we use them as a means to our own ends. (Savulescu 2002, 648-49)

In the literature, it is sometimes quickly assumed that dead individuals cannot be harmed by posthumous events. Proponents of this view argue that, as the deceased have no interests, there are no interests which can be harmed by the posthumous use of their body material (Spital and Erin 2002). By contrast, defenders of the concept of 'posthumous interests' argue that people do have critical interests that survive their death and may thus be harmed when these interests are violated (see, for example, Belliotti 2012).

Although this debate is highly fascinating, we cannot elaborate on it here and we shall suffice to say that we agree with those commentators who claim that we should respect the wishes of people also after their death, yet not out of a concern for harming them through posthumous events but for the sake of the living (Hamer and Rivlin 2003; Partridge 1981; Wicclair 2002). Generally, one can draw great reassurance and comfort, while alive, from the knowledge that one's preferences and values will be respected after death. Conversely, the expectation that one's preferences and values will be disregarded after death is likely to result in considerable anxiety and distress among the living (Wicclair 2002). As a result, the living have an interest in respecting the wishes of the deceased because in doing so they will strengthen the traditions that will protect their own interests in having posthumous influence (Partridge 1981).

Therefore, we would conclude that, even if the first three requirements for easy rescue would be fulfilled, no obligation to make one's body material available for research after death could be established on the basis of a duty of easy rescue when that research would disregard 
important values and wishes of the deceased, or, put differently, samples should only be removed after death if such removal and subsequent research would be compatible with the critical interests of the pre mortem person. Hence a duty of easy rescue can only be a conditional duty in the context at issue here, and it cannot be sufficient to justify a conscription regime. This leads us to the question as to how people's wishes with regard to research uses of their body material should be ascertained, or, put differently, what kind of consent regime should apply.

\section{CONSENT REGIMES REVISITED}

We have reviewed several arguments that could be put forward in support of a duty to participate in biomedical research that could extend to a duty to donate body material for research after death. We found that such a duty could be substantiated on the basis of a least two grounds (a duty to refrain from free-riding and a duty to contribute to the maintenance of public goods) and possibly a third ground (easy rescue, depending on how the conditions for an easy rescue are specified). However, since, as explained above, in each of these cases important conditions need to be fulfilled before the duty to donate body material for research after death would be triggered, this duty is always conditional. What does this imply with regard to the question which regime should govern the post mortem procurement of body material for research?

\subsection{No Consent: Conscription}

Can a conditional duty to donate body material for research after death commit us to accept a policy of conscription? Analyzing paradigmatic cases of conscription (e.g. military conscription; jury service; compulsory vaccination), Holm et al. conclude that conscription is only justified if its purpose cannot be achieved on a voluntary basis (Holm, Hofmann, and 
Solbakk 2009). However, in the context of post mortem removal of body material the claim that conscription is necessary is not plausible, for other, less coercive ways exist to achieve a sufficient supply of body material. Even with regard to research that relies heavily on body material which only becomes available after death, there does not seem to be a need to resort to compulsory removal before other strategies have been actively pursued.

If insufficient body material would be collected by resorting only to non-compulsory ways of post mortem removal, a policy of conscription could be justified on the basis of a duty to donate body material for research after death. However, in that case, the system of conscription would still need to comply with the conditions that attach to the duty. It could, for instance, be argued that, on the basis of a duty to contribute to the maintenance of public goods, samples from persons who did not donate body material while alive, may be conscripted after death if access to these samples would be limited to research projects which focus on obtaining biomedical knowledge that would unquestionably qualify as a public good. It has been proposed that this could be the case for research that is entirely uncontroversial and is likely to result in benefits that would be made available to everybody and would contribute to leveling social differences (Christensen 2009). However, in our view, these and similar suggestions raise overly challenging and arguably insurmountable problems related to the implementation and monitoring of the system of conscription. It would, for instance, be unclear who in each instance would decide whether conscription to a specific research project would be justified and what characteristics this project would need to have in order to be compatible with the conditional duty to make one's body material available for research after death. ${ }^{12}$

\footnotetext{
12 In addition, it should be noted that insurmountable problems would also arise with regard to monitoring whether persons had already donated body material while alive, especially taking into account that, even unbeknownst to the donor, body material removed for diagnostic or therapeutic purposes may have been used for research.
} 
We can conclude that, in the current state of affairs, since the claim of necessity is not fulfilled and major problems of implementation and monitoring would arise, a system of post mortem conscription of body material for research cannot be substantiated on the basis of a duty to donate body material for research after death.

\subsection{Presumed Consent Rather Than Explicit Consent}

By contrast, we would argue that the duty to donate body material for research after death is clearly strong enough to defend a system of presumed consent to post mortem removal of body material for research, rather than a regime of explicit consent which is the default option for participation in biomedical research. As we have seen, there are two and possibly three grounds to expect that individuals make their body material available for research after death. ${ }^{13}$ Yet, since the resulting duty will always be a conditional one, it is reasonable to leave it to the persons concerned to decide for themselves if they do not wish to donate and to expect them to take the necessary steps to opt out if they wish.

Indeed, it has been pointed out that a presumed consent system does not in any way restrict a person's right to self-determination, as long as the person was aware of the system and the implications of action or inaction, had a reasonable time period in which to object, and was offered adequate and accessible means of formally recording objections (Den Hartogh 2008). Furthermore, for many people the cost of contributing more than strictly required by duty are low. ${ }^{14}$ It may, for instance, be assumed that a lot of individuals do not have deep seated objections to the removal of body material after death, even in the absence of guarantees

\footnotetext{
13 Arguably, the duties identified may be similarly strong enough to defend a system of presumed consent for research use of (anonymised) residual biological materials. However, since in that kind of context additional elements might need to be considered, we will not expand upon this possibility here.

14 We thank one of the anonymous reviewers for pointing this out.
} 
that the research will comply with the conditions governing their duty (e.g. that the research will indeed result in knowledge constituting a public good).

However, in order to minimize the chance that body material would be removed after death from persons to whom no duty applied (e.g. because the intended research project is incompatible with their pre mortem values, implying that the fourth and fifth condition for the existence of a duty of easy rescue would not be met) and who did not want to go beyond the call of duty, several requirements would need to be fulfilled. First, awareness-raising campaigns should be launched to inform the public about the possibility of post mortem removal of body material for research purposes, the possible research uses and the consent regime in place. Second, procedures should be established to allow potential participants to register their unwillingness to make their body material available for research after death. ${ }^{15}$ Third, in the absence of a registered refusal, the next-of-kin must be consulted regarding the deceased person's wishes. Finally, it is conceivable that some people are unwilling to donate body material for certain types of research uses, while willing to do so for other research purposes. Therefore, besides the possibility for a blanket opt-out, it would seem to be advisable to also enable one to opt-out for certain generic categories of research uses. ${ }^{16}$

Admittedly, a system of presumed consent would imply the possibility that some people may opt out of making their body material available for research after death without having discharged their moral duty even though the conditions for the applicability of the duty were

15 In other words, post mortem donation of body material and donation of organs should be governed by separate registers.

16 Admittedly, it is impossible to compose an exhaustive list of such categories. Nevertheless, one could envisage a system wherein a limited number of categories are listed, followed by a text-box in which the person can write down any other research uses that she deems unacceptable.Further analysis is necessary to underpin more specific proposals in this regard; our focus here is on highlighting the reasons why, for the case of post mortem uses of body material for research, it is ethically permissible to depart from the default regime for participation in biomedical research, i.e. explicit consent, and to adopt a regime of presumed consent with proper safeguards. 
met. However, as noted earlier, there is no reason to legally enforce this moral duty as long as a sufficient supply of body material can be obtained by non-compulsory methods.

\section{CONCLUSION}

On the basis of a critical examination of various arguments invoked in the literature, we found that a duty to make one's body material available for research after death could be established on the basis of the duty to refrain from free-riding, the duty to contribute to the maintenance of public goods and, depending on the interpretation, possibly also the duty of easy rescue, although the latter ground applies less straightforwardly to the case under discussion here.

However, we also found that in each instance the duty to make one's body material available for research after death is a conditional one, hence this moral duty is not sufficient to justify the general adoption of a regime of post mortem conscription of body material for research purposes (and a conditional adoption would face massive monitoring problems). Moreover, we argued that a conscription regime, whether generalized or not, cannot be supported because it is unacceptable to resort to compulsory removal before other strategies to promote donation have been actively pursued and have been found to result in an insufficient supply of body material for research.

By contrast, we found that the duty to make body material available for research after death is strong enough to depart from explicit consent, i.e. the default option for participation in biomedical research, and to support a system of presumed consent. Finally, we made a number of suggestions to improve existing systems of presumed consent so as to minimize the likelihood that body material would be removed after death if this would go against the wishes of individuals regarding the use of body material after their death. 


\section{ACKNOWLEDGMENT}

The authors would like to express their deep gratitude to the anonymous reviewers for their many highly useful comments and suggestions to improve the quality of the manuscript.

\section{REFERENCES}

Ashburn, Ted, Sharon Wilson, and Barry Eisenstein. 2000. "Human Tissue Research in the Genomic Era of Medicine: Balancing Individual and Societal Interests.” Archives of Internal Medicine 160 (22): 3377-84.

Beauchamp, Tom, and James Childress. 2013. Principles of Biomedical Ethics. Seventh Edition. New York: Oxford University Press.

Belliotti, Raymond. 2012. Posthumous Harm: Why the Dead Are Still Vulnerable. Lanham, Md.: Lexington Books.

Brassington, Iain. 2011. "Defending the Duty to Research?” Bioethics 25 (1): 21-6.

Caplan, Arthur. 1984. "Is There a Duty to Serve as a Subject in Biomedical Research?” IRB: Ethics and Human Research 6 (5): 1-5.

Chan, Sarah, and John Harris. 2009. "Free Riders and Pious Sons-Why Science Research Remains Obligatory." Bioethics 23 (3): 161-71.

Christensen, Erik. 2009. "Biobanks and Our Common Good." In The Ethics of Research Biobanking, edited by Jan-Helge Solbakk, Soren Holm, and Bjorn Hofmann, 101-14. New York: Springer. 
Clark, Christopher, Matthew Kotchen, and Michael Moore. 2003. "Internal and External Influences on Pro-Environmental Behavior: Participation in a Green Electricity Program." Journal of Environmental Psychology 23 (3): 237-46.

Cockbain, Julian, and Sigrid Sterckx. 2011. "Something More is Necessary - Are Genes and Genetic Diagnostic Tests Statutory Subject Matter for US Patents?" Expert Review of Molecular Diagnostics 11 (2): 149-58.

de Melo-Martin, Inmaculado. 2008. "Response to Rosamond Rhodes." Newsletter on Philosophy and Medicine 7 (2): 13-4.

Den Hartogh, Govert. 2008. Farewell to Non-Commitment. Decision Systems for Organ Donation from an Ethical Viewpoint. The Hague: Centre for Ethics and Health.

Dworkin, Ronald. 1993. Life's Dominion. London: Harper Collins.

English, Veronica, and Ann Sommerville. 2003. "Presumed Consent for Transplantation: a Dead Issue after Alder Hey?” Journal of Medical Ethics 29 (3): 147-52.

Evans, Martyn. 2004. "Should Patients Be Allowed to Veto Their Participation in Clinical Research?” Journal of Medical Ethics 30 (2): 198-203.

Fabre, Cécile. 2006. Whose Body Is it Anyway? Justice and the Integrity of the Person. Oxford: Oxford University Press.

Forsberg, Joanna, Mats Hanson, and Stefan Eriksson. 2014. "Why Participating in (Certain) Scientific Research Is a Moral Duty." Journal of Medical Ethics 40 (5) : 325-8.

Hamer, Clare, and Michael Rivlin. 2003. “A Stronger Policy of OrganRetrieval from Cadaveric Donors: Some Ethical Considerations.” Journal of Medical Ethics 29 (3): 196-200. 
Harris, John. 2005. "Scientific Research Is a Moral Duty." Journal of Medical Ethics 31(4): $242-8$.

Hester, Micah. 2006. "Why We Must Leave Our Organs to Others." American Journal of Bioethics 6 (4): W23-8.

Hill, Thomas. 1992. Dignity and Practical Reason in Kant's Moral Theory. Ithaca: Cornell University Press.

Holm, Soren, Bjorn Hofmann, and Jan-Helge Solbakk. 2009. "Conscription to Biobank Research?" In The Ethics of Research Biobanking, edited by Jan-Helge Solbakk, Soren Holm, and Bjorn Hofmann, 255-62. New York: Springer.

James Scott. 2007. “Good Samaritans, Good Humanitarians.” Journal of Applied Philosophy 24 (3): $238-54$.

Lowrance, William, and Francis Collins. 2007. "Identifiability in Genomic Research.” Science 317: 600-2.

McGuire, Amy, and Richard Gibbs. 2006. "Genetics. No Longer De-Identified." Science 312: $370-1$.

Moore v. Regents of University of California (51 Cal.3d 120, Supreme Court of California), 9 July 1990.

Murphy, Liam. 2000. Moral Demands in Nonideal Theory. Oxford: Oxford University Press.

National Bioethics Advisory Commission. 1999. Research Involving Human Biological Materials: Ethical Issues and Policy Guidance. Rockville: National Bioethics Advisory Commission. Accessed September 13, 2013.

https://bioethicsarchive.georgetown.edu/nbac/hbm_exec.pdf 
Orentlicher, David. 2005. "Making Research a Requirement of Treatment: Why We Should Sometimes Let Doctors Pressure Patients to Participate in Research." Hastings Center Report 35 (5): $20-8$.

Partridge, Ernest. 1981. "Posthumous Interests and Posthumous Respect." Ethics 91(2): 24364.

Pogge, Thomas. 2002. "Responsibilities for Poverty-Related Ill Health.” Ethics \& International Affairs 16 (2): 71-9.

Rawls, John. 1971. A Theory of Justice. Cambridge: Harvard University Press.

Rhodes, Rosamond. 2005. "Rethinking Research Ethics.” American Journal of Bioethics 5 (1): $7-28$.

Rhodes, Rosamond. 2008. "In Defense of the Duty to Participate in Biomedical Research." American Journal of Bioethics 8 (10): 37-44.

Ripa, Louis. 1993. "A Half-Century of Community Water Fluoridation in the United States: Review and Commentary.” Journal of Public Health Dentistry 53 (1): 17-44.

Savulescu, Julian. 2002. "For and Against: No Consent Should Be Needed for Using Leftover Body Material for Scientific Purposes.” British Medical Journal 325 (7365): 648-51.

Schaefer, Owen, Ezekiel Emanuel, and Alan Wertheimer. 2009. "The Obligation to Participate in Biomedical Research." Journal of the American Medical Association 302 (1): 67-72.

Schmidt, Harald, and Shawneequa Callier. 2012. "How Anonymous Is 'Anonymous'? Some Suggestions towards a Coherent Universal Coding System for Genetic Samples.” Journal of Medical Ethics 38 (5): 304-9. 
Shapshay, Sandra, and Kenneth Pimple. 2007. "Participation in Biomedical Research Is an Imperfect Moral Duty: A Response to John Harris.” Journal of Medical Ethics 33 (7): 414-7.

Singer, Peter. 1972. "Famine, Affluence, and Morality." Philosophy \& Public Affairs 1 (3): 229-43.

Slote, Michael. 1977. "The Morality of Wealth." In World Hunger and Moral Obligation, edited by William Aiken and Hugh LaFollette, 124-47. Englewood Cliffs, JH: Prentice-Hall.

Smith P. 1990. "The Duty to Rescue and the Slippery Slope Problem." Social Theory and Practice 16 (1): 19-41.

Snyder, Jeremy. 2009. "Easy Rescues and Organ Transplantation.” HEC Forum 21 (1): 27-53.

Spital, Aaron, and Charles Erin. 2002. "Conscription of Cadaveric Organs for Transplantation: Let's at Least Talk about It.” American Journal of Kidney Diseases 39 (3): 611-5.

Spital, Aaron, and James Stacey Taylor. 2007. "Routine Recovery of Cadaveric Organs for Transplantation: Consistent, Fair, and Life-Saving." Clinical Journal of the American Society of Nephrology 2 (2): 300-3.

Sterckx, Sigrid. 2011. "Patenting and Licensing of University Research: Promoting Innovation or Undermining Academic Values?” Science \& Engineering Ethics 17 (1): 45-64.

Thomas, Cordelia. 2002. "Should the Law Allow Sentiment to Triumph over Science? The Retention of Body Parts." Discussion Paper Series 210. Massey University School of Accountancy. Accessed April 15, 2013.

http://www-accountancy.massey.ac.nz/Publications.htm

Van Assche, Kristof, Serge Gutwirth, and Sigrid Sterckx. 2013. "Protecting Dignitary Interests of Biobank Research Participants: Lessons from Havasupai Tribe v. Arizona Board of Regents." Law, Innovation and Technology 5(1): 55-85. 
Van Assche, Kristof, and Sigrid Sterckx. 2014. "The protection of human dignity in research involving human body material." In Humanity across International Law and Biolaw, edited by Britta van Beers, Luigi Corrias, and Wouter Werner, 265-287. Cambridge: Cambridge University Press.

Wachbroit, Robert, and David Wasserman. 2005. "Research Participation: Are We Subject to a Duty?" American Journal of Bioethics 5 (1): 48-9.

Wicclair Mark. 2002. "Informed Consent and Research Involving the Newly Dead." Kennedy Institute of Ethics Journal 12 (4): 351-72.

Williams, Bernard. 1990. “A Critique of Utilitarianism.” In Utilitarianism, For and Against, edited by John Smart and Bernard Williams, 82-117. Cambridge: Cambridge University Press.

Woolf, Steven, Robert Johnson, Robert Phillips, and Maike Philipsen. 2007. “Giving Everyone the Health of the Educated: An Examination of Whether Social Change Would Save More Lives Than Medical Advances." American Journal of Public Health 97 (4): 679-83. 